\title{
SPATA2 Gene
}

National Cancer Institute

\section{Source}

National Cancer Institute. SPATA2 Gene. NCI Thesaurus. Code C150063.

This gene plays a role in sperm formation. 